\title{
Prey Refuges in Emergent Vegetation Enhance Diving Beetle (Coleoptera: Dytiscidae) Diversity in Urban Ponds in the Presence of Predatory Fish
}

Wenfei Liao ( $\nabla$ wenfei.liao@helsinki.fi )

University of Helsinki https://orcid.org/0000-0002-1583-0408

Stephen Venn

University of Łódź https://orcid.org/0000-0002-0318-6256

Jari Niemelä

University of Helsinki https://orcid.org/0000-0003-2420-7391

\section{Research Article}

Keywords: aquatic insect, habitat complexity, macroinvertebrate, predation, urban blue infrastructure

Posted Date: April 30th, 2021

DOI: https://doi.org/10.21203/rs.3.rs-464602/v1

License: (c) (1) This work is licensed under a Creative Commons Attribution 4.0 International License.

Read Full License 


\section{Abstract}

Aquatic plants are important prey refugia for aquatic organisms, and their species richness is positively related with aquatic invertebrate species richness. Yet, little is known about how the quantity of refugia, i.e. aquatic vegetation cover, affect aquatic invertebrate assemblages and their habitat use in different levels of predation risks. Here, we investigated how provision of refugia affects diving beetle (Dytiscidae) species richness and abundance in the presence and absence of fish predators. We found that plant cover affected dytiscid populations differently: (1) At the pond level, dytiscid presence was positively correlated with increasing plant cover, both with and without fish, indicating the importance of emergent plants for aquatic biodiversity. (2) At the microhabitat level, dytiscid species richness and abundance responded positively to increasing plant cover in ponds with fish, but there was no such relationship in fishless ponds, emphasizing that the level of predation risks can alter prey species' use of prey refugia. Our findings provide evidence that the availability of both vegetated and non-vegetated microhabitats can benefit a diversity of aquatic invertebrates. We suggest maintaining variation in provision of emergent plant cover to retain high habitat heterogeneity in urban ponds to enhance freshwater biodiversity.

\section{Introduction}

Spatial prey refuges refer to places that can reduce predation risks of prey organisms [1]. The use of spatial refuges can effectively help prey avoid encountering predators, promote their survival, and enhance the coexistence of predator and prey organisms [2][3][4]. When the predators are generalists, prey organisms also benefit from the presence of alternative prey facilitated by prey refuges [4][5]. As spatial prey refuges can facilitate species coexistence and stabilise populations of predators and prey [6] [7], they can be used as a tool to enhance biodiversity.

Aquatic plants are important spatial refuges in aquatic ecosystems for many organisms, such as aquatic invertebrates [8]. Emergent plants are one type of aquatic plants categorized on the basis of their growth form. In the urban context, emergent plants have important values from both ecological and social perspectives, providing ecosystem services and nature-based solutions [9][10]. Emergent vegetation is often planted in urban wetlands primarily for runoff management purposes [11][12][13][14][15]. Yet, its presence also brings non-value ecosystem services, such as supporting wetland biodiversity by enhancing food resources for phytophagous species [16][17], and providing valuable habitat for sanctuary and breeding [18][19][20][21][22].

As spatial refuges, emergent plants increase habitat complexity and provide refuge for aquatic invertebrates [18][23]. In aquatic ecosystems, fish are one of the most common predators of aquatic invertebrates. In urban blue infrastructure, fish are sometimes used for recreational and management purposes [24] and can lead to a decrease in aquatic invertebrate diversity through excessive predation of vulnerable species [24][25] and decreasing habitat quality by destructing aquatic vegetation [26]. According to predatory-prey dynamics, the lack of refuges can lead to the extirpation of prey species, while the overabundance of prey refuges may result in the extirpation of predatory species [4]. Thus, it is 
important to consider the role of refuges in predator-prey dynamics, in order to promote the functionality of urban wetlands.

Water depth is a determinant of emergent plant species richness [27]. Water depth, as well as water turbidity, restricts the penetration of emergent plants due to light limitation in water, which determines the vegetation structure [28]. The seedlings of emergent plants normally only establish in shallow water, though they can colonize deeper water through rhizomal expansion [27]. In order to generate appropriate recommendations for the management of emergent aquatic vegetation, it is necessary to consider the biology of emergent plants in urban wetlands.

Aquatic invertebrate species richness have been found generally to be correlated with aquatic plant species richness [8][29]. Yet, it is unclear how aquatic plant cover, i.e. the quantity of spatial prey refuges, affects aquatic invertebrate diversity and their habitat use. If emergent plants are utilised as refuges to support biodiversity in urban wetlands, it is important to investigate how vegetation-preferring invertebrate taxa respond to plant cover. In this study, we focus on diving beetles (Dytiscidae), a family of aquatic insects with most species favouring and using aquatic vegetation for various purposes, including escaping from predators and ovipositing [30].

In our study, we address the following questions: (1) How does water depth limit the quantity of emergent plants? (2) How does the quantity of refuges, i.e. emergent plant cover, affect diving beetle species richness and abundance in predator-prey dynamics? (3) Are the effects of refuge quantity on dytiscids different in ponds with and without predatory fish?

\section{Results}

\section{Emergent plant occurrence and cover decreased with increasing water depth}

We found $1.20 \pm 1.21$ emergent plant species per plot, and $4.92 \pm 3.48$ emergent species per pond. The emergent plants we recorded were Alisma plantago-aquatica, Calla palustris, Carex spp., Comarum palustre, Eleocharis palustris, Equisetum fluviatile, Iris pseudacorus, Juncus spp., Phragmites spp., Sagittaria sagittifolia, Scirpus sylvaticus, Sparganium erectum, Schoenoplectus lacustris, Trichophorum cespitosum, Typha angustifolia, and Typha latifolia.

The occurrence part of our optimal zero-altered model showed that the probability of emergent plant occurrence decreased with increasing water depth ( $p$-value $<0.001$, Fig. 1a \& Appendix 1). The emergent plant cover also decreased with increasing water depth ( $p$-value $<0.001$, Fig. 1b). Emergent plant species richness, however, was not associated with depth.

\section{Emergent plant cover had a positive effect on dytiscid presence}


We recorded 400 dytiscid specimens of 43 species in the 26 ponds: 252 specimens of 34 species in May and 148 specimens of 32 species in July. The recorded species are listed in Appendix 4. At the pond level, the emergent plant cover had a significantly positive effect on the presence of dytiscids ( $p$-value $=0.023$, Appendix 3 ). When pond margins were occupied by over $25 \%$ emergent plants, the probability of dytiscid presence was $75 \%$ in ponds with fish and $100 \%$ in ponds without fish (Fig. 2). At the microhabitat level (between traps), our optimal GLMM models showed that vegetation cover had highly significant positive effects on both species richness and abundance of dytiscids in ponds with fish (Fig. 3a \& c, Appendix 3). Vegetation cover, however, had no effect on either species richness or abundance of dytiscids in fishless ponds at the trap level (Fig. 3b \&d, Appendix 3).

\section{Discussion}

We investigated how water depth affects emergent plant cover, and how the plant cover affects dytiscid diversity in ponds, both with fish and without. We found that emergent plant cover decreases with increasing water depth. The effects of plant cover on dytiscids are different at the pond level than the microhabitat level. At the pond level, increasing emergent plant cover has significantly positive effects on the presence of dytiscids in ponds both with and without fish. At the microhabitat level, the effects of plant cover on dytiscid diversity has noticeable differences between ponds with and without fish. In ponds with fish, both dytiscid species richness and abundance are positively correlated with increasing plant cover (Fig 3 a \& c). In ponds without fish, plant cover has no effect on dytiscid species richness and abundance at the microhabitat level (Fig 3 b \& d).

\section{Emergent plant cover decreases with water depth}

Our results indicate that when the water is deeper than $50 \mathrm{~cm}$, there is a low probability of finding emergent plants. Yet, we found no association between plant species richness and water depth, which is contradictory with the findings of 55 urban wetlands in Japan that emergent plant species richness is negatively associated with increasing water depth [28]. Emergent plants are only capable of establishing in shallow but not deep waters, although they can expand into deeper water via rhizomal growth [27]. In urban ponds, water turbidity can be high, due to the effects of intensive land use [28], and the action of benthic fish [41], which limits light penetration [42] and consequently restricts emergent plant growth [27].

\section{Emergent plants as prey refuges to promote species coexistence}

The importance of emergent plant cover to dytiscids can be different at the pond level from the microhabitat level (trap level). At the pond level, the presence or absence of emergent plant cover determines the occurrence probability of dytiscids, because most dytiscid species prefer water with vegetation [30]. Larger areas of emergent plants at the pond margins are more important in ponds with 
fish than in ponds without fish, due to the heavy predation pressure from fish. This reflects the importance of emergent plants as prey refuges for dytiscids, in order for them to establish a stable population. Aquatic plant species richness has a positive correlation with aquatic invertebrate species richness [8] [29]. Our result of the positive effects of plant cover on dytiscids (in the presence of predators) emphasizes the importance of prey refuge quantity as a conservation tool to support aquatic biodiversity.

Dytiscid population dynamics at the microhabitat level is different in ponds with fish than in fishless ponds. These differences indicate that predation pressure is different in the two types of ponds. Fish are known to have strong negative effects on dytiscid species richness and abundance [24]. In fishless aquatic habitats, however, dytiscids are top predators in the food chain, although not completely free from other predators [43]. Emergent plants can serve as dytiscid refuges, providing sanctuary from predators [44] and reducing attacking rate and success [4][45].

Prey refuges can also facilitate utilization of alternative prey in both quality and quantity for generalist predators. Emergent plants are often associated with other aquatic invertebrates, such as Hemiptera [37] and Diptera [46]. These invertebrates are alternative prey for generalist predators, such as Crussian carps, which are found in some of our ponds [24], and which can reduce predation pressure on dytiscids. When generalist predators switch their diets, the switching behaviour can reduce the risk of local extinctions of scarce prey species as a result of competition with dominant prey species [5]. Prey refuges, thus, can stabilise the predator-prey dynamics of an ecosystem and promote the coexistence of prey and predator species, as well as the coexistence of different prey species.

\section{Predation pressure and dytiscids' use of prey refuges}

In fishless ponds, dytiscids are not free from predators. Intraspecific and interspecific predation is common among dytiscids, especially among their larvae [43]. Other potential predators of dytiscids include aquatic insects [47], amphibians [48], waterbirds [49], and mammals [50], summaried in Table 1. However, these predators exert a lower level of predation pressure on dytiscids compared with predatory fish, because predatory insects have a lower gut capacity, and dytiscids comprise only a small proportion of the diet of the other predators mentioned.

The presence of refuges can increase habitat complexity and lead to shifts of hunting modes in predatory insects, including dytiscids and Odonata larvae. Some predatory insects shift from an active hunting mode in habitats with a simple structure to an ambush strategy in vegetated habitats [51][52]. With an ambush strategy, Dytiscus decreases its predation on Graphoderus spp. [45][52]. The presence of refuges can balance encounter rates between prey and predators and capture rates of predators [53].

The presence of emergent plants can also influence the foraging preferences of non-fish vertebrate predators (Table1). Many non-fish predators of dytiscids prefer to forage in vegetated microhabitats [54] [55][56]. This foraging preference of predators indicates that, in fishless ponds, the predation pressure on 
dytiscids in vegetated microhabitats is not necessarily lower than in non-vegetated microhabitats Dytiscids need instantaneous responses and escape to non-vegetated microhabitats to avoid predation when these non-fish predators feed in vegetated microhabitats. In this case, non-vegetated microhabitats serve as refugia for dytiscids. Habitats with structural heterogeneity, thus, can facilitate co-existence of predator and prey species.

As non-fish predators exert low predation pressure on dytiscids, in fishless ponds, dytiscids can spend more time foraging in open water, which is favoured by other invertebrates, such as Trichoptera [37][58]. Refuges help prey species to avoid predators, but safe habitats do not necessarily provide them with good foraging [3]. Emergent plants also provide dytiscids' prey with refugia as dytiscids' attacking rate and success is often higher in habitats without vegetation than in vegetated habitats [45]. Dytiscids have more opportunities to forage in non-vegetated microhabitats in fishless ponds than in ponds with fish. We assume that predation pressure and predators' foraging behaviours may have contributed to dytiscids' lack of preference for vegetated or non-vegetated microhabitats in fishless ponds.

\section{Implications for wetland management}

On the basis of this study, we recommend managing ponds for habitat heterogeneity, with different levels of structural complexity. Although vegetation can increase habitat complexity, both vegetated and nonvegetated microhabitats are beneficial to support aquatic biodiversity. For instance, emergent plants provide valuable habitats and act as refugia in predator-prey dynamics for many dytiscid species and other aquatic invertebrates that often occur in vegetated habitats. However, not all aquatic invertebrates are associated with vegetation. For instance, other important taxa such as waterboatmen (Corixidae) and caddisfly (Trichoptera) larvae seem to prefer open water [37][58]. Therefore, variation in provision of plant cover and open water can benefit different taxa and support higher levels of biodiversity.

We recommend maintaining a diversity of microhabitats, characterized by different water depths. As mentioned above, the provision of both heterogeneous aquatic vegetation and open water can benefit different taxa. Also from a human perspective, diversity of aquatic vegetation and open water are two key factors determining aesthetic appreciation regarding blue infrastructure [60]. Dense emergent vegetation promotes a sense of naturalness, but urban residents seem tolerant of only a certain level of naturalness in urban wetlands [61]. Management of vegetation is only necessary when vegetation cover is excessive, particularly in shallow ponds where there would be potential for homogenizing vegetation spread.

\section{Materials \& Methods}

\section{Study Site and Data Collecting}

We conducted our fieldwork in 26 ponds divided between 11 sites in the Helsinki Metropolitan Area $\left(60.1699^{\circ} \mathrm{N}, 24.9384^{\circ} \mathrm{E}\right)$, Finland [31]. Eleven ponds were with predatory fish, while 15 ponds were free from fish. The sizes of the ponds varied from 0.013 hectare to 1.18 hectare (mean $=0.27 \pm 0.31$ hectare) 
with shoreline length in spring (May) from $59 \mathrm{~m}$ to $559 \mathrm{~m}$ (mean $=210 \pm 132 \mathrm{~m}$ ). The pond surroundings were covered by $15.95-56.41 \%$ impermeable surfaces (mean $=29.31 \% \pm 9.98 \%$ ) within a distance of 500 $\mathrm{m}$.

We sampled dytiscids by operating 1-L activity traps without bait horizontally in water for 48 hours [32] leaving air bubbles in traps. More details regarding the trapping method are described in Liao et al. [24]. We sampled dytiscids with activity traps instead of handnet sweeping in many water beetle studies [8] to eliminate bias in dytiscid sampling caused by temporary human disturbance, although activity traps may underestimate some small-sized species [33]. We preserved the specimens in $70 \%$ ethanol until identification using a microscope in the laboratory. We identified dytiscid species according to Nilsson and Holmen [30], and followed Nilsson and Hajek [34] for the nomenclature.

Emergent plants were the main components of the aquatic vegetation growing in our study pond margins. Little submerged and floating plants were found in the pond margins. We surveyed emergent plant cover and identified the plants to species or genus level. We estimated emergent plant cover at the microhabitat level and at the pond level. At the microhabitat level, we surveyed the vegetation in $1 \times 1 \mathrm{~m}$ plots with the activity traps at the plot centre; we also measured the water depth at each activity trap. At the pond level, we walked around each pond and estimated the percentage of the pond margins that were vegetated with emergent plants. The vegetation included both newly emerged plants and the previous year's plant residuals, because the aquatic vegetation in our wetlands was not managed annually. We collected data of dytiscid assemblages and environmental variables at the microhabitat level in May 2019 , and data of dytiscid presence/absence and the percentage of plant cover at the pond level in May and July 2018-2019.

\section{Statistical Analysis}

To investigate the effects of water depth on emergent plant species richness and emergent vegetation cover, we applied generalised linear mixed models (GLMM) with Poisson distribution and beta distribution, respectively. We included sites and ponds as potential random effects in our initial models, because the observations of aquatic vegetation might have been two-way nested: our traps were nested within ponds, and ponds were nested within sites. The GLMM models, however, failed to produce similar percentages of zeros to our observed data. Therefore, we applied zero-altered models to analyse 1) how water depth affected the occurrence of emergent vegetation at the microhabitat level, and 2) how water depth affected the species richness and the cover of emergent plants when emergent plants were present. In order to fit a model with beta distribution, we made a minor transformation to the vegetation cover data [35]. The full models are described in Appendix 1.

We applied GLMM with binomial distribution to investigate how the presence or absence of dytiscids was affected by emergent plant cover, sampling month, and the presence or absence of fish at the pond level. We could not analyse how dytiscid species richness and abundance were affected by vegetation cover at the pond level due to the zero inflation in our dataset. At the microhabitat level, we applied GLMM with Poisson distribution to investigate the effects of emergent plants on dytiscid species richness and 
abundance in ponds with and without fish. Due to the collinearity between emergent plant species richness and cover, we only included the emergent plant cover in our models for two reasons: 1 . Previous studies [8][36][37] have already explored the correlation between plant and aquatic invertebrate species richness; 2. the main target in this study is to investigate how the quantity of prey refuges affects vegetation-preferring aquatic invertebrate diversity. We also included the interactions between fish and emergent vegetation cover as one of the covariates, and ponds and sites as random effects in our initial models of both the pond level and the microhabitat level. The full models are described in Appendix 2 and Appendix 3.

We conducted a backward selection manually and chose the optimal models based on the lowest Akaike Information Criterion (AIC) values. To validate our models, we simulated 10,000 datasets to ensure our optimal GLMM models were able to produce similar percentage of zeros to our observed data [38]. We applied GLMM and zero-altered models with R package "glmmTMB"[39] in R software, version 3.6.1 [40].

\section{Declarations}

\section{Acknowledgement}

Our research was supported by Chinese Scholarship Council (Grant 201707960009 to

WL). We would like to thank Petri Nummi for helping in the field.

\section{Authorship}

Wenfei Liao designed the study, collected and analysed the data, and led the writing. Stephen Venn and Jari Niemelä revised the manuscript critically for important intellectual contents and structure. All authors gave final approval for publication.

\section{Data Availability}

We will make the data available on fairdata.fi when the manuscript is accepted.

\section{Ethical Statement}

The authors declare no conflict of interests.

\section{References}

1. Sih, A. Prey refuges and predator-prey stability. Theor. Popul. Biol. 31 (1), 1-12 (1987). 
2. Murdoch, W. W. \& Oaten, A. (1975). Predation and population stability. In Advances in ecological research (Vol. 9, pp. 1-131). Academic Press. https://doi.org/10.1016/S0065-2504(08)60288-3

3. Boeing, W. J. (2010). Defensive avoidance. Encyclopedia of Animal Behavior. pp 476-480. Academic Press. https://doi.org/10.1016/B978-0-08-045337-8.00331-4

4. Ghosh, J., Sahoo, B. \& Poria, S. Prey-predator dynamics with prey refuge providing additional food to predator. Chaos, Solitons \& Fractals. 96, 110-119 (2017).

5. Estes, J., Crooks, K. \& Holt, R. D. (2013). Predators, ecological role of. Encyclopedia of Biodiversity (Second Edition), pp 229-249. https://doi.org/10.1016/B978-0-12-384719-5.00117-9

6. Taylor, R. J. Predation (Springer Science \& Business Media, 2013).

7. Hassell, M. P. The Dynamics of Arthopod Predator-Prey Systems.(MPB-13), Volume 13 Vol. 111 (Princeton University Press, 2020).

8. Law, A. et al. The effectiveness of aquatic plants as surrogates for wider biodiversity in standing fresh waters. Freshw. Biol. 64 (9), 1664-1675 (2019).

9. García-Llorente, M., Martín-López, B., Díaz, S. \& Montes, C. (2011). Can ecosystem properties be fully translated into service values? An economic valuation of aquatic plant services. Ecological Applications, 21(8), 3083-3103.

10. Dobbie, M. \& Green, R. Public perceptions of freshwater wetlands in Victoria, Australia. Landscape and Urban Planning. 110, 143-154 (2013).

11. Ellis, J. B., Shutes, R. B., Revitt, D. M. \& Zhang, T. T. Use of macrophytes for pollution treatment in urban wetlands. Resources, conservation and recycling. 11 (1-4), 1-12 (1994).

12. Horppila, J. \& Nurminen, L. The effect of an emergent macrophyte (Typha angustifolia) on sediment resuspension in a shallow north temperate lake. Freshw. Biol. 46 (11), 1447-1455 (2001).

13. Dhote, S. \& Dixit, S. Water quality improvement through macrophytes-a review. Environmental Monitoring and Assessment. 152 (1-4), 149-153 (2009).

14. Horppila, J., Kaitaranta, J., Joensuu, L. \& Nurminen, L. Influence of emergent macrophyte (Phragmites australis) density on water turbulence and erosion of organic-rich sediment. Journal of Hydrodynamics. 25 (2), 288-293 (2013).

15. Vymazal, J. Emergent plants used in free water surface constructed wetlands: a review. Ecological engineering. 61, 582-592 (2013).

16. Klopatek, J. M. \& Stearns, F. W. Primary productivity of emergent macrophytes in a Wisconsin freshwater marsh ecosystem320-332(American Midland Naturalist, 1978).

17. Bakker, E. S. et al. Herbivory on freshwater and marine macrophytes: a review and perspective. Aquat. Bot. 135, 18-36 (2016).

18. Dibble, E. D. \& Harrel, S. L. Largemouth bass diets in two aquatic plant communities. Journal of Aquatic Plant Management. 35, 74-78 (1997).

19. Jackson, D. J. Egg-laying and egg-hatching in Agabus bipustulatus L., with notes on oviposition in three species of Agabus (Coleoptera: Dytiscidae). Transactions of the Royal Entomological Society 
of London. 110 (3), 53-80 (1958).

20. Jackson, D. J. Observations on egg-laying in Ilybius fuliginosus Fabricius and I. ater Degeer (Coleoptera: Dytiscidae), with an account of the female genitalia. Transactions of the Royal Entomological Society of London. 112 (3), 37-52 (1960).

21. Brittain, J. E. \& Sartori, M. In Encyclopedia of insectspp. 328-334(Academic Press, 2009). Ephemeroptera:(Mayflies)

22. Goertzen, D. \& Suhling, F. Promoting dragonfly diversity in cities: major determinants and implications for urban pond design. Journal of Insect Conservation. 17 (2), 399-409 (2013).

23. Cazzanelli, M., Warming, T. P. \& Christoffersen, K. S. Emergent and floating-leaved macrophytes as refuge for zooplankton in a eutrophic temperate lake without submerged vegetation. Hydrobiologia. 605 (1), 113-122 https://doi.org/10.1007/s10750-008-9324-1 (2008).

24. Liao, W., Venn, S. \& Niemelä, J. Environmental determinants of diving beetle assemblages (Coleoptera: Dytiscidae) in an urban landscape. Biodiversity and Conservation. 29, 2343-2359 https://doi.org/10.1007/s10531-020-01977-9 (2020).

25. Johansson, F. \& Brodin, T. Effects of fish predators and abiotic factors on dragonfly community structure. Journal of Freshwater Ecology. 18 (3), 415-423 https://doi.org/10.1080/02705060.2003.9663977 (2003).

26. Kloskowski, J. Impact of common carp Cyprinus carpio on aquatic communities: direct trophic effects versus habitat deterioration. Fundamental and Applied Limnology-Archiv furHydrobiologie. 178 (3), 245 (2011).

27. Weisner, S. E. Within-lake patterns in depth penetration of emergent vegetation. Freshw. Biol. 26 (1), 133-142 (1991).

28. Akasaka, M., Takamura, N., Mitsuhashi, H. \& Kadono, Y. Effects of land use on aquatic macrophyte diversity and water quality of ponds. Freshw. Biol. 55 (4), 909-922 (2010).

29. Gledhill, D. G., James, P. \& Davies, D. H. Pond density as a determinant of aquatic species richness in an urban landscape. Landscape ecology. 23 (10), 1219-1230 (2008).

30. Nilsson, A. N. \& Holmen, M. The Aquatic Adephaga (Coleoptera) of the Fennoscandia and Denmark. Ii. Dytiscidae: II-Dytiscidea (Brill, 1995).

31. Liao, W., Venn, S. \& Niemelä, J. (2021, preprint). Diving Beetle (Coleoptera: Dytiscidae) Community Dissimilarity Reveals How Low Landscape Connectivity Restricts the Ecological Value of Urban Ponds.

32. Elmberg, J., Nummi, P., Pöysä, H. \& Sjöberg, K. Do intruding predators and trap position affect the reliability of catches in activity traps? Hydrobiologia. 239 (3), 187-193 https://doi.org/10.1007/BF00007676 (1992).

33. Hilsenhoff, W. L. Effectiveness of bottle traps for collecting Dytiscidae (Coleoptera)377-380(The Coleopterists' Bulletin, 1987). 
34. Nilsson, A. N. \& Hájek, J. (2019). A world catalogue of the family Dytiscidae, or the diving beetles (Coleoptera, Adephaga). Version 1. I. 2019.

35. Smithson, M. \& Verkuilen, J. A better lemon squeezer? Maximum-likelihood regression with betadistributed dependent variables. Psychological methods. 11 (1), 54 (2006).

36. Palmer, M. (1981). Relationship between species richness of macrophytes and insects in some water bodies in the Norfolk Breckland.

37. Hassall, C., Hollinshead, J. \& Hull, A. Environmental correlates of plant and invertebrate species richness in ponds. Biodiversity and Conservation. 20 (13), 3189-3222 (2011).

38. Zuur, A. F. \& leno, E. N. A protocol for conducting and presenting results of regression-type analyses. Methods in Ecology and Evolution. 7 (6), 636-645 https://doi.org/10.1111/2041-210X.12577 (2016).

39. \& Bolker, B. M. (2017). glmmTMB balances speed and flexibility among packages for zero-inflated generalized linear mixed modeling. The R journal, 9(2), 378-400.

40. R Core Team (2019). R: A language and environment for statistical computing. R Foundation for Statistical Computing, Vienna, Austria. URL https://www.R-project.org/.

41. Wetzel, R. G. Limnology: lake and river ecosystems (gulf professional publishing, 2001).

42. Thornhill, I. (2013). Water quality, biodiversity and ecosystem functioning in ponds across an urban land-use gradient in Birmingham, UK (Doctoral dissertation, University of Birmingham).

43. Culler, L. E., Ohba, S. Y. \& Crumrine, P. In Ecology, systematics, and the natural history of predaceous diving beetles (Coleoptera: Dytiscidae)pp. 363-386(Springer, Dordrecht, 2014). Predator-prey interactions of dytiscids

44. Nilsson, A. N., Elmberg, J. \& Sjoberg, K. (1994). Abundance and species richness patterns of predaceous diving beetles (Coleoptera, Dytiscidae) in Swedish lakes. Journal of Biogeography,197206.

45. Yee, D. A. Behavior and aquatic plants as factors affecting predation by three species of larval predaceous diving beetles (Coleoptera: Dytiscidae). Hydrobiologia. 637 (1), 33-43 (2010).

46. Van de Meutter, F., Cottenie, K. \& De Meester, L. Exploring differences in macroinvertebrate communities from emergent, floating-leaved and submersed vegetation in shallow ponds. Fundamental and Applied Limnology/Archiv Für Hydrobiologie. 173 (1), 47-57 https://doi.org/10.1127/1863-9135/2008/0173-0047 (2008).

47. Larson, D. J. Odonate predation as a factor influencing dytiscid beetle distribution and community structure. Quaestiones Entomologicae. 26 (2), 151-162 (1990).

48. Fasola, M. \& Canova, L. Feeding habits of Triturus vulgaris, T. cristatus and T. alpestris (Amphibia, Urodela) in the northern Apennines (Italy). Italian Journal of Zoology. 59 (3), 273-280 (1992).

49. Thomas, G. J. Autumn and winter feeding ecology of waterfowl at the Ouse Washes, England. Journal of Zoology. 197 (1), 131-172 https://doi.org/10.1111/jzo.1982.197.1.131 (1982). 
50. Haberl, W. Food storage, prey remains and notes on occasional vertebrates in the diet of the Eurasian water shrew, Neomys fodiens. FOLIA ZOOLOGICA-PRAHA- 51 (2), 93-102 (2002).

51. Warfe, D. M. \& Barmuta, L. A. Habitat structural complexity mediates the foraging success of multiple predator species. Oecologia. 141 (1), 171-178 https://doi.org/10.1007/s00442-004-1644-x (2004).

52. Michel, M. J. \& Adams, M. M. Differential effects of structural complexity on predator foraging behavior. Behav. Ecol. 20 (2), 313-317 https://doi.org/10.1093/beheco/arp005 (2009).

53. Janssen, A., Sabelis, M. W., Magalhães, S., Montserrat, M. \& Van der Hammen, T. Habitat structure affects intraguild predation. Ecology. 88 (11), 2713-2719 https://doi.org/10.1890/06-1408.1 (2007).

54. Griffiths, R. A. \& Mylotte, V. J. Microhabitat selection and feeding relations of smooth and warty newts, Triturus vulgaris and T. cristatus, at an upland pond. in mid-Wales. Ecography. 10 (1), 1-7 https://doi.org/10.1111/j.1600-0587.1987.tb00731.x (1987).

55. Rychlik, L. (1997). Differences in foraging behaviour between water shrews: Neomys anomalus and Neomys fodiens.Acta Theriologica, 42(4).

56. Nummi, P., Sjöberg, K., Pöysä, H. \& Elmberg, J. Individual foraging behaviour indicates resource limitation: an experiment with mallard ducklings. Canadian journal of zoology. 78 (11), 1891-1895 https://doi.org/10.1139/z00-142 (2000).

57. a] Nummi, P., Pöysä, H., Elmberg, J. \& Sjöberg, K. In Aquatic Birds in the Trophic Web of Lakespp. 247-252(Springer, Dordrecht, 1994). Habitat distribution of the mallard in relation to vegetation structure, food, and population density https://doi.org/10.1007/978-94-011-1128-7_23

58. De Szalay, F. A. \& Resh, V. H. Factors influencing macroinvertebrate colonization of seasonal wetlands: responses to emergent plant cover. Freshw. Biol. 45 (3), 295-308 (2000).

59. Johansson, F. Foraging modes in an assemblage of odonate larvae-effects of prey and interference. Hydrobiologia. 209 (1), 79-87 https://doi.org/10.1007/BF00006721 (1991).

60. Gledhill, D. G., James, P. \& Davies, D. H. (2005). Urban pond:a landscape of multiple meanings.

61. Ngiam, R. W. J., Lim, W. L. \& Collins, C. M. A balancing act in urban social-ecology: human appreciation, ponds and dragonflies. Urban ecosystems. 20 (4), 743-758 (2017).

\section{Tables}

Table 1 Predators of dytiscids in fishless ponds and their foraging behaviours. 


\begin{tabular}{|c|c|c|}
\hline Predators & Example & Foraging behaviours \\
\hline $\begin{array}{l}\text { Aquatic } \\
\text { insects }\end{array}$ & Odonata larvae & $\begin{array}{l}\text { 1. ambush with high prey density, active hunting with low } \\
\text { prey density [47] } \\
\text { 2. shifting hunting modes with the presence of aquatic plants } \\
\text { [59] }\end{array}$ \\
\hline Amphibians & $\begin{array}{l}\text { Smooth newts } \\
\text { (Lissotriton } \\
\text { vulgaris) }\end{array}$ & 1. most active in vegetated microhabitats [48] \\
\hline Waterbirds & $\begin{array}{l}\text { Mallards } \\
\text { (Anas } \\
\text { platyrhynchos) }\end{array}$ & $\begin{array}{l}\text { 1. limited moving in good habitats [57] } \\
\text { 2. prefer habitats with emergent vegetation [49][56][57] }\end{array}$ \\
\hline Mammals & $\begin{array}{l}\text { Eurasian water } \\
\text { shrews } \\
\text { (Neomys fodiens) }\end{array}$ & $\begin{array}{l}\text { 1. forage both in and out of water [50] } \\
\text { 2. prefer shallow water with vegetation [55] }\end{array}$ \\
\hline
\end{tabular}

\section{Figures}
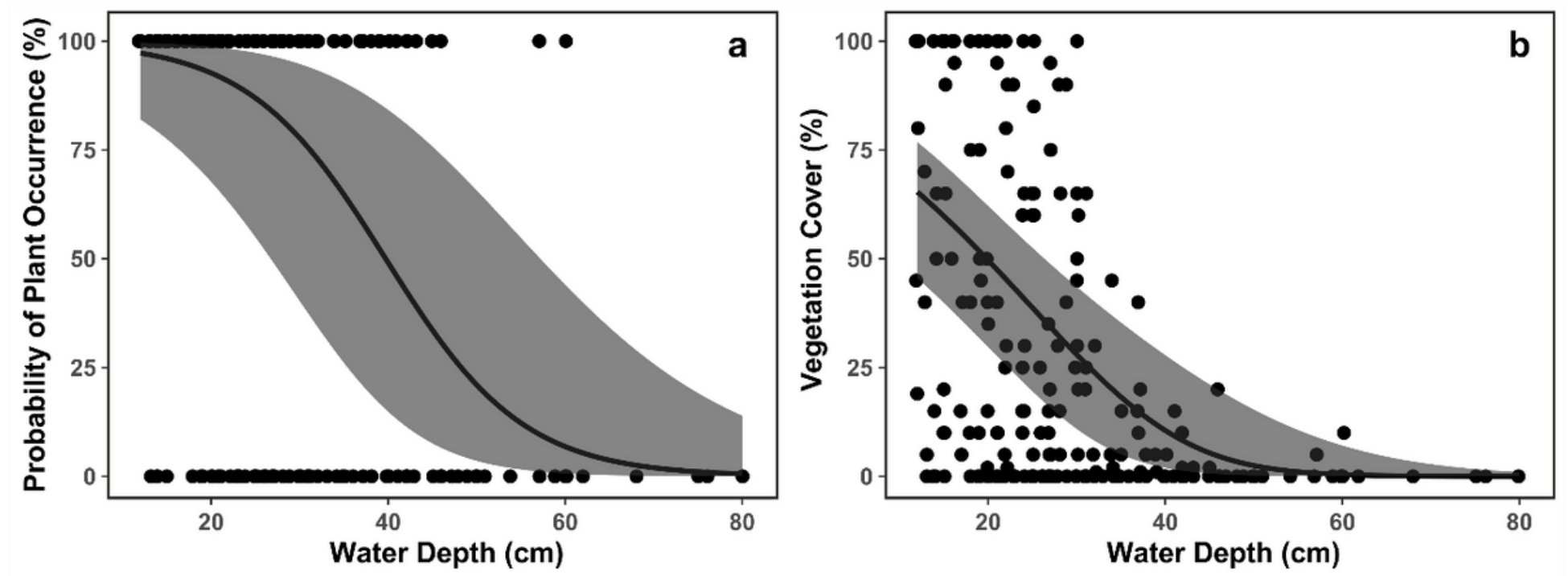

Figure 1

(a) The probability of plant occurrence decreased with increasing water depth; (b) the coverage of emergent vegetation decreased increasing water depth. The black dots are our field observations. 


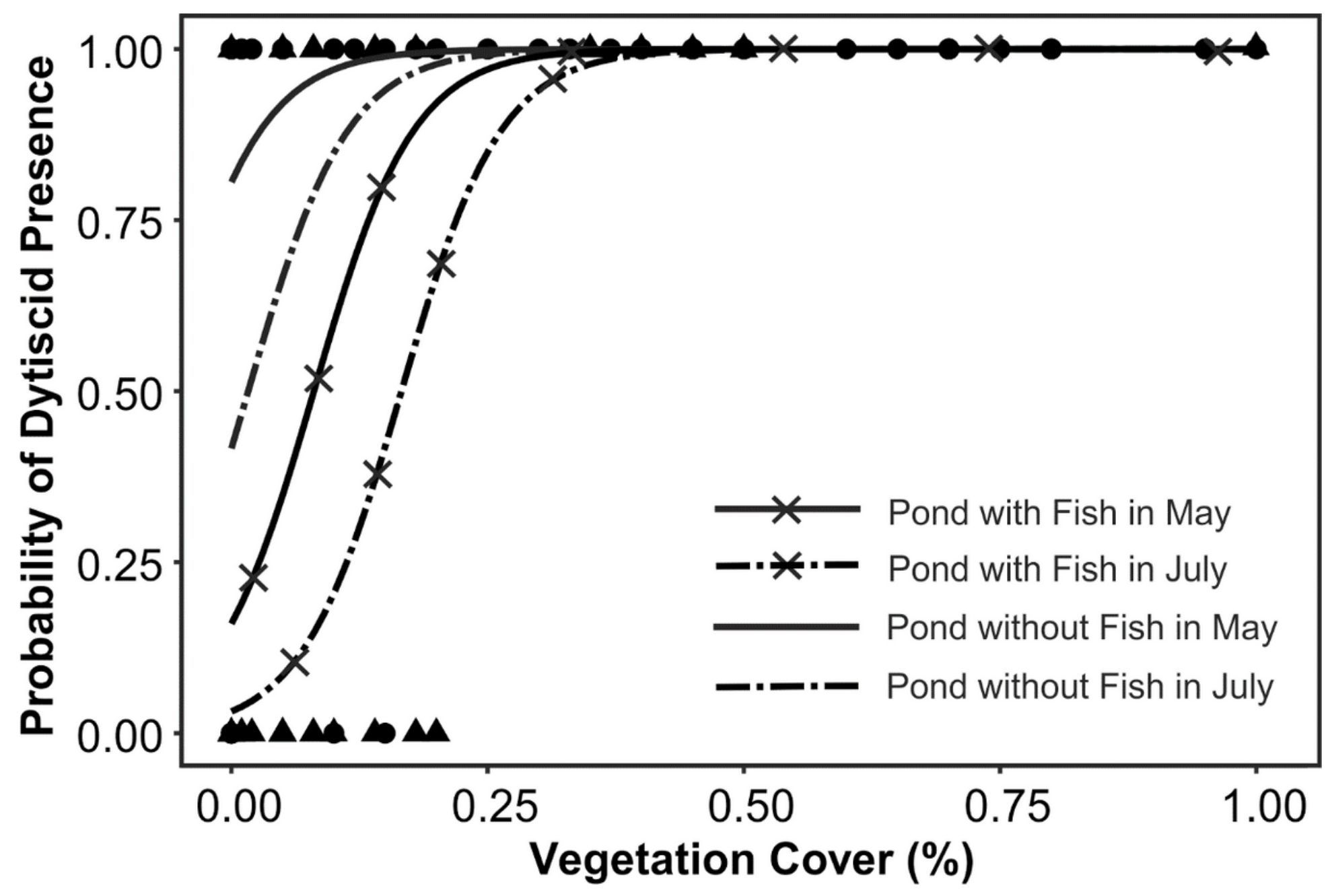

Figure 2

The estimated probability of dytiscid presence in a pond increases with the vegetation coverage of pond margins. The black triangles are observations in ponds with fish, and black dots are observations in ponds without fish. 
Ponds with Fish
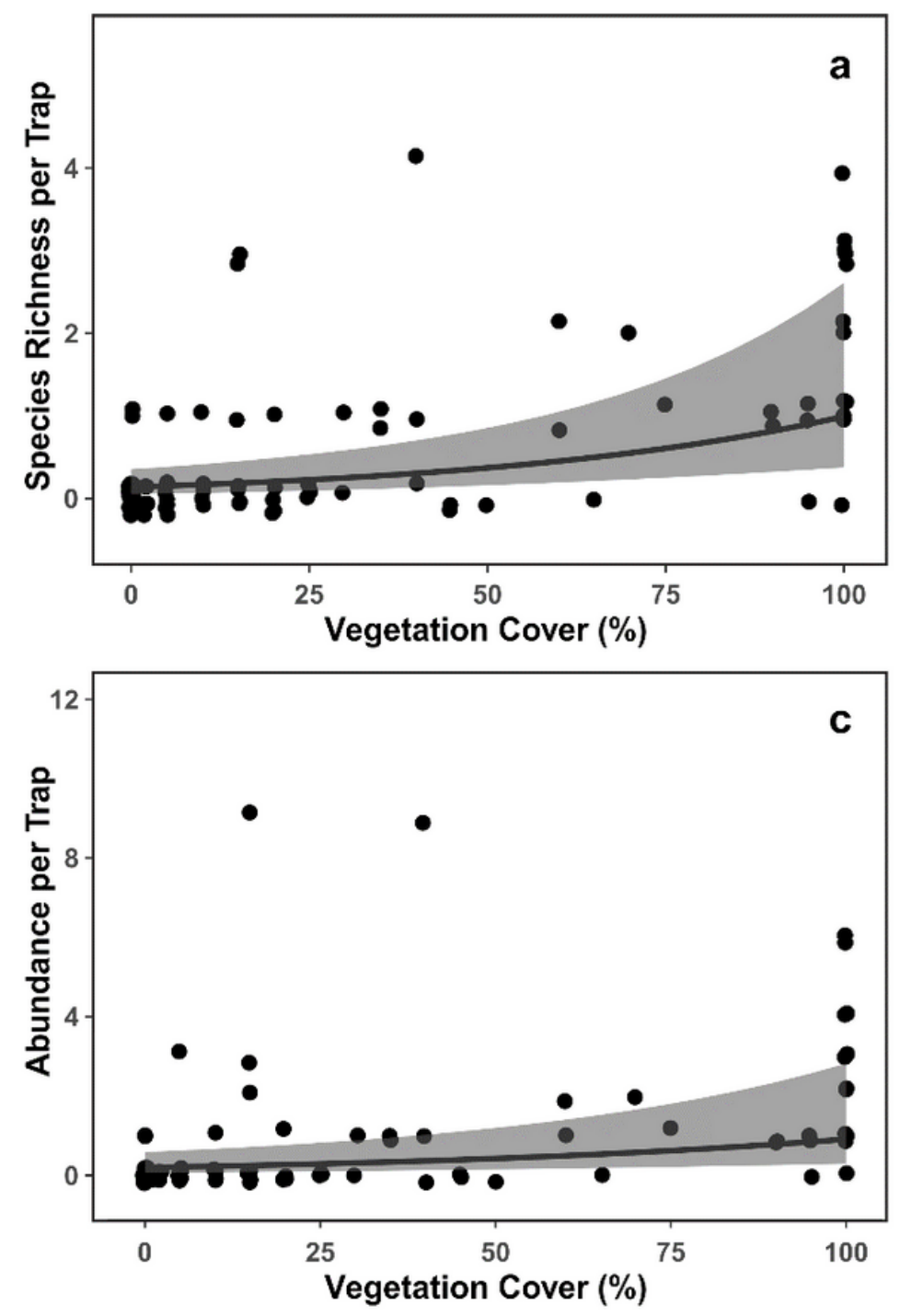

Ponds witouth Fish
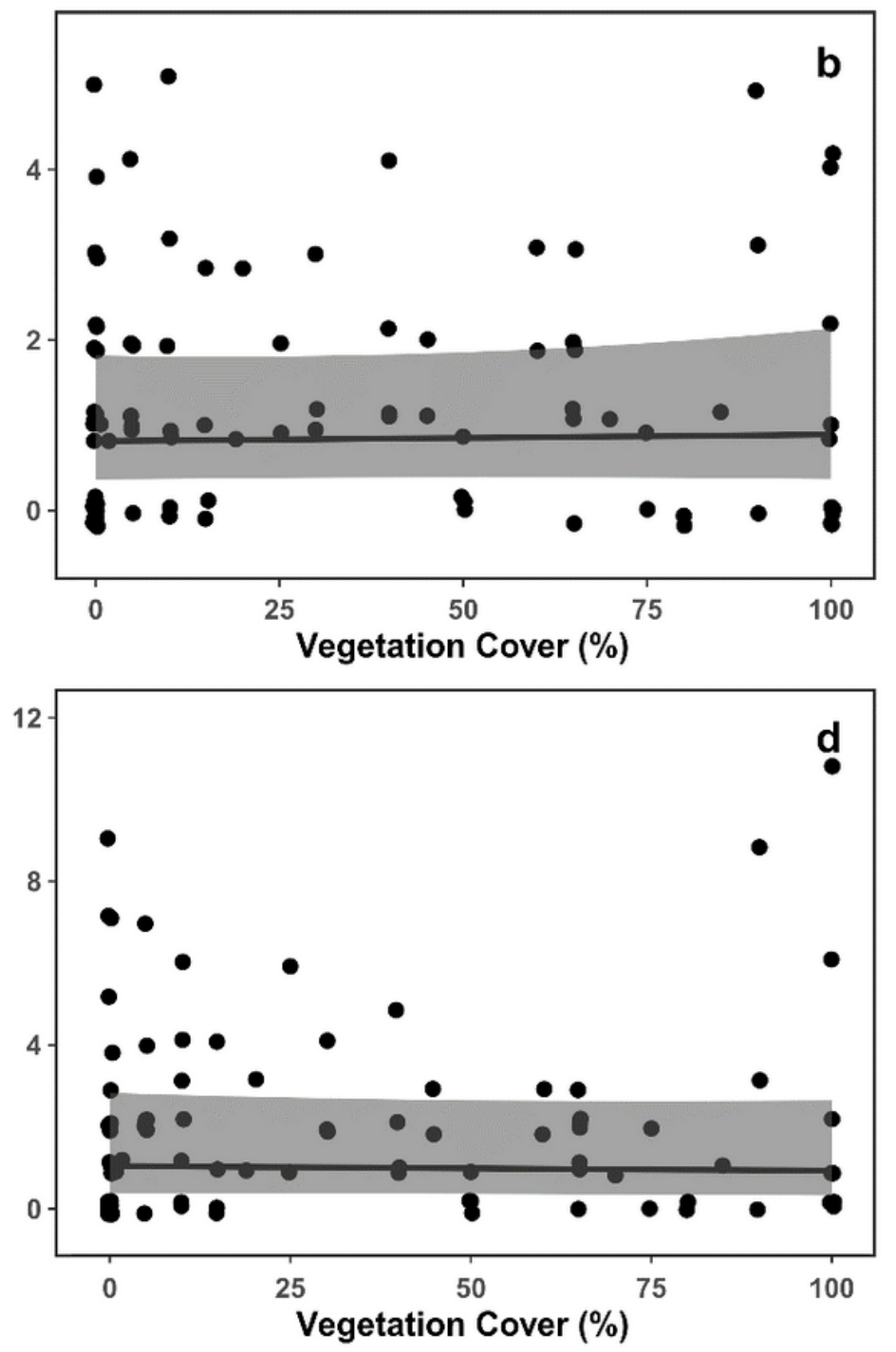

Figure 3

At the microhabitat level, dytiscid species richness (a) and abundance (c) are positively correlated with emergent plant cover in ponds with fish, while they are not correlated with emergent plant cover in ponds without fish (b \& d). The black dots are individual trap observations, plotted with slight artificial jittering.

\section{Supplementary Files}

This is a list of supplementary files associated with this preprint. Click to download.

- Supplementary27.04.2021.docx 